\title{
On Early-Warning Mechanism of Specialty Setting and Adjustment in Higher Vocational Education Based on Multi-index Big Data Extraction
}

\author{
Cao Jun and Zhang Xuelong
}

\begin{abstract}
Based on the data extracted from the talent training status, the third-party institution and the large data in the process of teaching and learning within the school, this research analyses the setting factors of the early-warning index and Operating mechanism and attempts to establish the self-optimization early warning system of specialty setting and adjustment in higher vocational education in order to carry out diagnosis and improvement in daily work.
\end{abstract}

Index Terms - Early warning mechanism, big data, multi index, specialty setting and adjustment.

\section{INTRODUCTION}

With the rapid development of China's economy and society, the target of higher education shifts from elite education to popularization education. The scientific and reasonable specialty setting and the adaptation of professional connotation construction to the development of the market determine the survival and the development of colleges and universities. Because of the different educational management system at home and abroad, the mechanism of specialty setting and adjustment in higher education is different.

The United States are considered as a global leader in the quality of higher education. The certification system as the core of its quality assurance system includes the institution certification and professional certification at the national level [1]. The Council for Higher Education Accreditation (CHEA) give the definition of "certification" is: Certification is a process of assessing the quality of an institution or professional external in order to improve educate quality. Ref [2] The United States Department of Education (USED) defines "certification" as "certification is a mark issued to Institutions or specialties by the certification body. It can prove that now and in the foreseeable future can achieve education aim and the standards specified by the certification body. Ref. "[3] the certification system is the contradiction between quantity and quality of higher education in the United States and the high degree of autonomy and decentralized management. Ref. [4] the authentication modes are implemented in 5 steps: developing certification

\footnotetext{
Manuscript received December 25, 2016; revised February 16, 2017. This work was supported in part by Shanghai higher vocational education quality improvement decision-making consultation service platform construction projects in 2015 .

Cao Jun is with Shanghai SIPO Polytechnic, Shanghai, China (e-mail 47886005@qq.com).

Zhang Xuelong is with the Management and Research of Higher Vocational Education, China (e-mail: xuelongz@aliyun.com).
}

standards, self-assessment, field trips, decision of certification body and re-evaluation. Ref. [5] their decentralized management system brings certain flexibility and autonomy in specialty setting and adjustment at the school level. In their colleges and universities, market regulation is the dominant factor of specialty setting and adjustment and labor market the key factor. While a new career appears in the society, colleges and universities offer the corresponding elective courses in the first place. Only when the market demand for the new career has grown to a considerable size and the required knowledge structure is relatively clear, the specialty can be set up officially. The new specialty generation pattern as Career-Curriculum-Specialty is formed in this way. Ref. [6] it fully shows the dynamic interaction between American colleges and universities and the labor market.

While the management in China tends to be more centralized, the Ministry of Education formulates the specialty catalogue. The evaluation system of the Ministry of Education has 11 indicators, including specialty setting, talents cultivation objectives, curriculum system, course, teaching process, professional key ability and quality training, teaching environment, Industry-Academy-Research cooperation, teaching staff, the quality of student ability, graduates employment, professional characteristics. Generally, the assessment is conducted once every five years. The education department in provincial or municipal government and the colleges at provincial or municipal level has also set up an early - warning mechanism of specialty setting and adjustment. For example, the Education Department of Jiangsu Province sets up an early warning system which obtains a comprehensive index according to some indicators such as the employment rate six months after graduation, the average monthly income, the relevance of study to present job, the employment status, the job satisfaction etc. In Hubei province, the Education Department has proposed regulations: for three consecutive years, the specialty will be revoked if the rate for the registration examination is less than $10 \%$ and the specialty will stop the enrollment if the initial graduate employment rate is less than $50 \%$.

As the third-party evaluation institution, the company MYCOS thinks that the ultimate basis of professional structure adjustment is the social needs and the training quality and meanwhile the characteristics of candidates should also be considered. The adjustment of specialty structure in colleges should be carried out in three steps: the adjustment of orientation, that of cultivation and that of settings. According to MYCOS, the main indicators that 
reflect the quality of professional training include the graduates' employment rate six months after graduation, the average monthly income six months after graduation, the relevance of study to present job, the turnover rate six months after graduation, the job satisfaction, etc. [7].

In summary, the Career-Curriculum-Specialty as the new specialty generation pattern in USA mainly lies in the adjustment of the old specialty and the new one. The practice in China shows that the duration of the periodic warnings is longer than one year. This paper focuses on extracting the daily teaching data in the school, with the aid of MYCOS third-party assessment data, integrating the talents cultivation status data platform, as well as the internal and external feedback information from school and other means of large data, builds an early warning mechanism of specialty settings and content adjustment which focuses on the "Process". It aims to set the specialty reasonably and to strengthen the specialty connotation construction. It can be expected that the internal and external supervision and guarantee mechanism in school is formed and that the objective evaluation and timely feedback of specialty construction and talent training quality in time is made. In this way, the purpose of sustainable development of specialty construction can be realized.

\section{THE ESTABLISHMENT OF EARLY WARNING SYSTEM FOR MULTI-INDEX DATA EXTRACTION}

\section{A. The Value of Big Data to Specialty Setting and Adjustment}

In 2001, the company named Gartner in the USA put forward a concept of "big data" for the first time. Ref. [8] into 2012 , the term "big data" is increasingly being mentioned. It refers to all the data for analysis and processing, rather than a shortcut to random analysis (sample survey). In the past, the data obtained through the survey are the structured data, while in the era of large data, the data, especially for the diversified data sources, are more unstructured data, which are transformed into structural data through cleaning, sorting and filtering [9].

Data stored in the process of teaching and learning include a lot of information, such as feedback from within and outside the school information, talents cultivation status data platform and MYCOS third-party assessment data. Big data comprehensive digital statistical analysis and multi-dimensional statistical rankings according to professions can provide important decision-making research and reference for the school in setting up the specialty reasonably and adjusting the professional connotation.

\section{B. Establish the Early-Warning System of Fitness Index Based on Large Data Statistical.}

Starting from the needs of adaptation to the industry, enterprise and society, we should consider decomposing the indicators so as to reflect the influence of different variables on enrollment, employment and talents training. Combining with the survey of experts in vocational education, teachers in similar institutions and Enterprise managers, design a "fitness" evaluation index system based on large data multi-channel. There are 4first-grade indexes, namely, internal outcome indexes, internal cause indexes, external obvious indexes and external invisible indexes. There are 11 second-grade indexes, namely, the quality of talents training ,the data of teaching and studying style, teaching staff, teaching design and organization, Cooperative Teaching between Colleges and Enterprises, training bases, employment quality, enrollment quality, market changes, government regulation, industry and enterprises demands, and 53 third-grade indexes. Research group adopts the method of experts sorting statistics. The indexes are divided into five grades by importance and assessed by experts according to their importance, and the weight of each index is calculated. The specific results are shown in the table1.

TABLE I: EVALUATING INDEX AND WEIGHT OF PROFESSIONAL "ADAPTABILITY"

\begin{tabular}{|c|c|c|c|c|c|}
\hline $\begin{array}{l}\text { first-grade } \\
\text { index }\end{array}$ & weight & $\begin{array}{l}\text { second-grade } \\
\text { index }\end{array}$ & weight & third-grade index & weight \\
\hline \multirow{17}{*}{$\begin{array}{l}\text { internal } \\
\text { outcome } \\
\text { indexes }\end{array}$} & \multirow{17}{*}{0.25} & \multirow{10}{*}{$\begin{array}{l}\text { the quality of } \\
\text { talents training }\end{array}$} & \multirow{10}{*}{0.59} & The rate of obtaining a vocational qualification certificate & 0.12 \\
\hline & & & & PET-A passing rate & 0.07 \\
\hline & & & & CET-4 passing rate & 0.08 \\
\hline & & & & Computer-Grade-One passing rate & 0.08 \\
\hline & & & & Prize less for 3 years in professional skills competition & 0.09 \\
\hline & & & & Students' satisfaction of teaching & 0.10 \\
\hline & & & & Importance and satisfaction of core curriculum & 0.12 \\
\hline & & & & Students' belief in quality promotion & 0.10 \\
\hline & & & & Students' satisfaction of basic ability to work & 0.13 \\
\hline & & & & Satisfaction of core knowledge & 0.11 \\
\hline & & \multirow{7}{*}{$\begin{array}{l}\text { the data of } \\
\text { teaching and } \\
\text { studying style }\end{array}$} & \multirow{7}{*}{0.41} & student absences & 0.14 \\
\hline & & & & The outflow rate of school register changes & 0.12 \\
\hline & & & & The ratio of students attending a retaken course & 0.09 \\
\hline & & & & Students' craluation of teaching & 0.15 \\
\hline & & & & The comprehensive evaluation of teaching inspection & 0.16 \\
\hline & & & & Poor performance in classroom & 0.16 \\
\hline & & & & Classroom teaching evaluation & 0.18 \\
\hline \multirow{16}{*}{$\begin{array}{l}\text { intemal } \\
\text { cause } \\
\text { indexes }\end{array}$} & \multirow{16}{*}{0.24} & \multirow{4}{*}{ teaching staff } & \multirow{4}{*}{0.30} & The pupil-teacher ratio & 0.28 \\
\hline & & & & Double - division structure & 0.30 \\
\hline & & & & The proportion of graduate degree of above & 0.20 \\
\hline & & & & The proportion of senior titles & 0.22 \\
\hline & & \multirow{5}{*}{$\begin{array}{l}\text { teaching design } \\
\text { and organization }\end{array}$} & \multirow{5}{*}{0.21} & Multiple parties formulate talents training plan & 0.22 \\
\hline & & & & The curriculum system setting and timely adjustment & 0.19 \\
\hline & & & & The fitness of curriculum standard & 0.21 \\
\hline & & & & Innovative Application of Teaching Means & 0.20 \\
\hline & & & & Training syllabus, training instruction & 0.18 \\
\hline & & \multirow{3}{*}{$\begin{array}{l}\text { Cooperative } \\
\text { Teaching } \\
\text { between } \\
\text { Colleges and } \\
\text { Enterprises }\end{array}$} & \multirow{3}{*}{0.22} & $\begin{array}{l}\text { The Degree of Enterprise 's Participation in the Practice } \\
\text { Teaching of Core Courses }\end{array}$ & 0.35 \\
\hline & & & & $\begin{array}{l}\text { The Degree of Enterprise 's Participation in Students' skill } \\
\text { evaluation }\end{array}$ & 0.30 \\
\hline & & & & $\begin{array}{l}\text { Students' evaluation for Guidance and Management of } \\
\text { Intership }\end{array}$ & 0.35 \\
\hline & & \multirow{4}{*}{ training bases } & \multirow{4}{*}{0.27} & $\begin{array}{l}\text { The number of training rooms built by the } \\
\text { college and enterprise }\end{array}$ & 0.24 \\
\hline & & & & $\begin{array}{l}\text { The number of training programs Developed by the } \\
\text { college and enterprise }\end{array}$ & 0.31 \\
\hline & & & & $\begin{array}{l}\text { The average area of practice for each student } \\
\text { (squaremetres / person) }\end{array}$ & 0.22 \\
\hline & & & & $\begin{array}{l}\text { The average value of teaching equipment for each student } \\
\text { (yun / person) }\end{array}$ & 0.23 \\
\hline \multirow{10}{*}{$\begin{array}{l}\text { extemal } \\
\text { obvious } \\
\text { indexes }\end{array}$} & \multirow{10}{*}{0.31} & \multirow{6}{*}{$\begin{array}{l}\text { employment } \\
\text { quality }\end{array}$} & & The rate of employment contract & 0.16 \\
\hline & & & & $\begin{array}{l}\text { The rate of graduates employment after graduation for } \\
\text { six months }\end{array}$ & 0.20 \\
\hline & & & 0.57 & $\begin{array}{l}\text { the average monthly income after graduation for six } \\
\text { months }\end{array}$ & 0.15 \\
\hline & & & & the tumover rate after graduation for six months & 0.13 \\
\hline & & & & The relevance of work and professional & 0.18 \\
\hline & & & & Students' satisfaction of employment status & 0.18 \\
\hline & & & & the acceptance rate of Enrollment Plan & 0.26 \\
\hline & & enrollment & & The completion rate of Enrollment Plan & 0.29 \\
\hline & & quality & 0.43 & Registration Rate & 0.24 \\
\hline & & & & Admission test results & 0.21 \\
\hline & & nat son & & $\begin{array}{l}\text { The growth rate of national economy } \\
\text { (national and regional) }\end{array}$ & 0.30 \\
\hline & & markel changes & 0.23 & The changes of labor demands (national and regional) & 0.35 \\
\hline & & & & income changes (national and regional) & 0.35 \\
\hline extemal & & & & Employment security policy (national and regional) & 0.18 \\
\hline invisible & 0.20 & government & & Industry devclopment planning （national and regional ) & 0.28 \\
\hline indexes & & regulation & 0.3 & Industrial policy (national and regional) & 0.24 \\
\hline & & & & Education reform policy（national and regional） & 0.30 \\
\hline & & Industry & & Demand for Human Resources & 0.49 \\
\hline & & enterprises & 0.45 & The changes of Professional and technical skills & 0.31 \\
\hline & & demands & & The changes of talent migration skills and general skills & 0.20 \\
\hline
\end{tabular}

Each of the third-grade indexes has a corresponding nominal value and its source basis. If the data is derived from the internal daily teaching monitoring and the internal and external evaluation of college-enterprise, the nominal value is determined by the professional ranking. If the data is from the talent training status data platform, the value is determined by the national higher vocational assessment 
indicators. If the data come from MYCOS third-party evaluation institutions, it is determined according to the average level of national higher vocational colleges. As for the nominal value of the external implicit indicators, it is measured in accordance with its national policy, social marketing and the matching degree of enterprise skills demand.

\section{The Establishment of Early Warning Operation Mechanism Based on Large Data Extraction}

\section{1) Response mechanism}

In order to achieve truly Specialty adjustment, Professional early warning must be timely and a "procedural" warning should be implemented. It requires that any unsuitable motives, actions and results encountered in the process of talent training should be considered and improved. Then an effective response mechanism should be established. In the specific operation, research group establishes the internal and external combination of effective mechanism that is based on college-enterprise joint and plays a role in educational monitoring, evaluation and correction. The principal is responsible at school level, which has college-enterprise cooperation professional construction guiding committee and professional talent training quality supervising committee. The dean's office, the supervision office and the recruitment and employment office, as the core of the internal and external mechanism department, focus on internal quality and guarantee, quality traceability, supervision and improvement, external tracking and evaluation, down to the secondary colleges and teaching-research offices [10].

\section{2) The response path and responding time}

Early warning indicators, sources of data acquisition, responsible departments and corresponding period are specified in the following Table II in the process of response. The response path is shown in Fig. 1.

TABLE II: ThE RESPONSE PATH OF PROFESSIONAL EARLY WARNING MECHANISM

\begin{tabular}{|c|c|c|c|c|c|c|}
\hline number & data & $\begin{array}{l}\text { responsible } \\
\text { department }\end{array}$ & sources of data & Acquistion subject & $\begin{array}{l}\text { Acquisition time } \\
\text { per year }\end{array}$ & $\begin{array}{c}\text { responding } \\
\text { period }\end{array}$ \\
\hline 1 & $\begin{array}{c}\text { Enterpise } \\
\text { research } \\
\text { (information, } \\
\text { data) }\end{array}$ & $\begin{array}{c}\text { Employment } \\
\text { Office }\end{array}$ & $\begin{array}{c}\text { HR manager, } \\
\text { project manager, } \\
\text { engineering technicians }\end{array}$ & $\begin{array}{c}\text { Departments, } \\
\text { Professional director, } \\
\text { secondary colleges }\end{array}$ & October-December & \multirow{5}{*}{ year } \\
\hline 2 & $\begin{array}{l}\text { Summary and } \\
\text { Analysis of } \\
\text { Intemship }\end{array}$ & $\begin{array}{c}\text { Employment } \\
\text { Office }\end{array}$ & $\begin{array}{l}\text { intemstip, trainee, } \\
\text { specialized teacher, } \\
\text { teaching master }\end{array}$ & \begin{tabular}{c|} 
Field work \\
management platfom, \\
career counselor
\end{tabular} & May to June & \\
\hline 5 & $\begin{array}{l}\text { Training } \\
\text { quality } \\
\text { evaluation }\end{array}$ & $\begin{array}{c}\text { Supervision } \\
\text { Office }\end{array}$ & $\begin{array}{l}\text { Previous Graduates, } \\
\text { Graduates }\end{array}$ & $\begin{array}{l}\text { The third-party } \\
\text { evaluation institutions-- } \\
\text { MYCOS }\end{array}$ & September & \\
\hline 6 & $\begin{array}{c}\text { Employment } \\
\text { quality } \\
\text { evaluation }\end{array}$ & \begin{tabular}{|c|c|c|}
$\begin{array}{c}\text { Employment } \\
\text { Office }\end{array}$ \\
\end{tabular} & Graduates & \begin{tabular}{|l|} 
The third-party \\
evaluation institutions-- \\
NEW jincin \\
\end{tabular} & December & \\
\hline 4 & $\begin{array}{c}\text { Teaching } \\
\text { support } \\
\text { system } \\
\text { (Teaching } \\
\text { staff, Practical } \\
\text { conditions, } \\
\text { Management } \\
\text { and services) }\end{array}$ & $\begin{array}{l}\text { Dean's } \\
\text { Office, } \\
\text { Secondary } \\
\text { colleges }\end{array}$ & $\begin{array}{l}\text { talent training status } \\
\text { data platform }\end{array}$ & $\begin{array}{l}\text { Related departments, } \\
\text { Professional diretor, } \\
\text { teacher }\end{array}$ & October & \\
\hline 7 & $\begin{array}{l}\text { Tracking } \\
\text { teaching and } \\
\text { study style }\end{array}$ & $\begin{array}{c}\text { Dean's } \\
\text { Office, } \\
\text { students' } \\
\text { affairs office }\end{array}$ & teacher, student & $\begin{array}{c}\text { Dean's Office, } \\
\text { secondary colleges, } \\
\text { teaching.-research office }\end{array}$ & casual inspection & $\begin{array}{l}\text { timely } \\
\text { response }\end{array}$ \\
\hline 8 & $\begin{array}{l}\text { Teaching } \\
\text { inspection at } \\
\text { the beginning, } \\
\text { the midterm } \\
\text { and final }\end{array}$ & $\begin{array}{l}\text { Dean's } \\
\text { Office }\end{array}$ & $\begin{array}{l}\text { Professional director, } \\
\text { teacher, student }\end{array}$ & $\begin{array}{c}\text { Dean's Office, } \\
\text { secondary colleges, } \\
\text { teaching-research office }\end{array}$ & $\begin{array}{l}\text { At the beginning, } \\
\text { the midterm and } \\
\text { final }\end{array}$ & quarter \\
\hline 9 & $\begin{array}{c}\text { Teaching } \\
\text { process } \\
\text { monitoring }\end{array}$ & $\begin{array}{l}\text { Dean's } \\
\text { Office }\end{array}$ & $\begin{array}{l}\text { Classsoom, Training } \\
\text { room }\end{array}$ & $\begin{array}{l}\text { Dean's Office, } \\
\text { Supervision Office, } \\
\text { dean's office of } \\
\text { secondary colleges }\end{array}$ & Once a week & week \\
\hline 10 & $\begin{array}{l}\text { Revising and } \\
\text { Improving for } \\
\text { Talents } \\
\text { Training } \\
\text { program }\end{array}$ & $\begin{array}{l}\text { Dean's } \\
\text { Office }\end{array}$ & teaching-research office & $\begin{array}{l}\text { Dean's Oflice, } \\
\text { Supervision Office }\end{array}$ & June to August & year \\
\hline
\end{tabular}

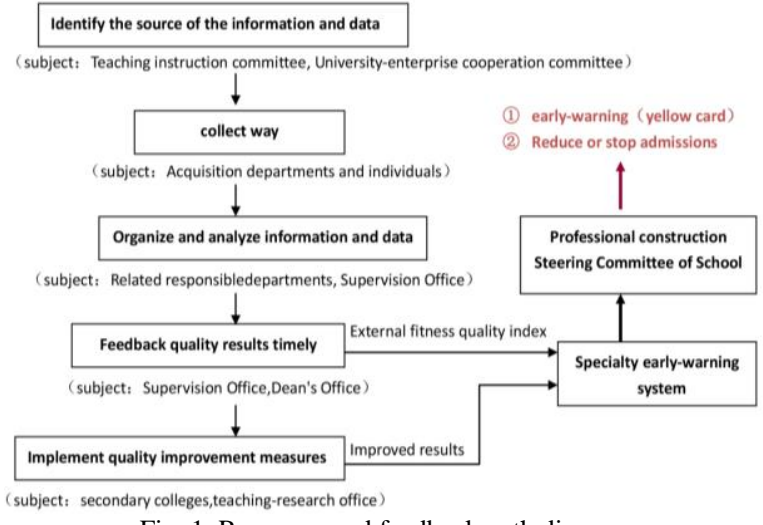

Fig. 1. Response and feedback path diagram.

The timeliness of the data acquisition determines the response time of the adjustment mechanism. The relevant departments of the school collect data in a timely manner at the preset time. When a third-grade index is lower than the nominal value or does not conform to requirements, System is bright yellow light, and the related Professional director will immediately make a diagnosis. At the end of one semester and one academic year, the system automatically counts the scores based on the weight assigned to each indicator. When $30 \%$ of the indicators are in the lower professional rankings, the related Professional director will find out the reasons for timely diagnosis. There will be significant improvements in professional content in the next semester and in the next academic year. If we determine the next annual enrollment plan, it is still bright yellow, namely to suspend the professional enrollment. We will give it an academic year of diagnosis. If there were still no signs of improvement, specialty will be canceled.

\section{CONCLUSION}

In higher vocational colleges, the professional director should systematically carry out investigation and research the method of which should combine internal and external factors of the index. The object of investigation and research includes the enterprises, the college, other vocational colleges with the similar specialty setting and all previous graduates. The content includes the report of the situation of the industry and the related enterprises, the corresponding analysis of professional position, the basic requirements of employees, the type of profession qualification certificate, the specialty structure, the situation of the enrollment and the employment of students, the teaching situation etc. It helps to understand the development of related industries and future development trend in China, to make clear of economic construction and social development demand for professional talents, to better grasp the direction of running a college, to identify the orientation of talents training, to understand the professional ability, to gain access to job tasks, to reasonably develop curriculum and teaching content, to implement the necessary conditions for the practice teaching, to regulate the direction of teachers' training and formation, as well as to lay a foundation for exploring the curriculum system suitable for the professional level.

And then according to the internal and external factors of early warning system, research and contrast analysis for 
every specialty should be carried out so as to determine if the enrollment will be continued or the direction of professional connotation in the next year will be adjusted. It is required to analyze the reasons and make plans for remedy according to the reaction of the explicit indicators in the process of talent cultivation. This proves the objectivity and practicality of early-warning system of specialty setting and adjustment based on the talent training status, the third-party institution and the large data in the process of teaching and learning within the school. It can be generalized and applied to each profession for adjustment and optimization. And it can even provide reference for establishing early - warning mechanism of Specialty Setting and Adjustment in Higher Vocational Colleges in Shanghai.

\section{REFERENCES}

[1] D. F. Westerheijden and M. Leegwater, Working on the European Dimension of Quality, Ministry of Education, Culture and Sciences, Zoetermeer, the Netherlands, p. 55, 2003

[2] Council for Higher Education Accreditation. [Online]. Available: http://www.chea.org/recognition/Recognition1998.asp

[3] Overview of Accreditation in the United States. [Online]. Available: https://www2.ed.gov/admins/finaid/accred/accreditation.html\#history

[4] L. C. Dighton, The Encyclopedia of Education [M], New York: The Macmillan and the Free Press, pp. 56-57, 1971.

[5] J. S. Eaton. An Overview of U.S. Accreditation. [Online]. Available: http://www.chea.org/pdf/overview us accred 8-03.pdf

[6] A. LI, "A probe into the specialty setup and adjustment strategy in the new era from the differences between China and USA," China Electric Power Education, vol. 37, no. 29, pp. 30-31, 2014
[7] Mycos research Institute, Annual Report on Social Needs and Training Quality of Shanghai SIPO Polytechnic College, Social Science Academic Press, Beijing, 2016

[8] Big data. [Online]. Available: http://www.Gartner.com/it-glossary/big - ata

[9] J. Guan, Z. Liu, and Y. Liu, "A comparative study of big data layout and application of major internet companies at home and abroad," Chinese Media Science and Technology, pp. 45-49, Sep. 2012.

[10] Y. Wang, "Research on specialty setting and early-warning mechanism of higher vocational education," Education and Vocational, pp. 31-33, Feb. 2015

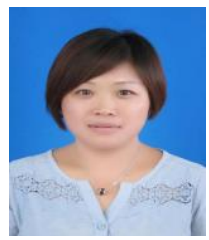

Cao Jun is lecturer, graduated from East China University of Science and Technology with the master of business administration, and research on the management of higher vocational education. She is the author and coauthor of a book and five papers.

Zhang Xuelong graduated from Suzhou University of P.R.China then worked at China University of Mining and Technology and also he has been a professor from 1995, a member of CCAST (World Lab.). Since the March of 2000, he has joined Shanghai Medical Instrumentation College. Now he works at Shanghai Sipo Polytechnic. He has long engaged in educational management and teaching research experience. His main research interests are in the management and research of higher vocational education, medical physics and modern physics and its application. He is the author and coauthor of five books and more than forty-five papers which were published in the academic journals such as Phys. Lett. A, Eur. J. Phys., Acta Physics Sinica, Chinese Journal of Leasers, Acta Mathematica Scientia, Acta Photonica Sinica at home and abroad. 